\title{
THE RELATIONSHIP OF PLAY ACTIVITIES IN COGNITIVE DEVELOPMENT OF CHILDREN AGED 1 - 2 YEARS OLD
}

\author{
Hanita \\ PG PAUD FKIP Universitas Widya Gama Mahakam Samarinda \\ nitahanita87@gmail.com
}

\begin{abstract}
Parents, schools and government should pay great attention to early childhood education and knowledge. Early childhood is nurtured and stimulated according to the wishes and abilities of each child with the hope that they can grow accordingly and develop as they should. Play is every child's right. Playing is a land for children to express all forms of behavior that are fun and without coercion. Play has a role to support children's growth and development, especially in the development of cognitive aspects. This study identifies the role of play activities on knowledge of children aged 1-2 years. Quantitative research and using a simple paradigm of the relationship of two variables. The data analysis technique used in this study was the parametric correlation analysis perarson product moment. The results of the study The value of $\operatorname{sig}(0.003)<\alpha$ then $\mathrm{H} 0$ is rejected. So that there is a correlation between the role of play activities and the cognitive development of children 1-2 years. The correlation coefficient value shows the effect of the role of playing activities on cognitive development of children $1-2$ years of 0.598 or $59.8 \%$. So that the correlation is $40.2 \%$, maybe there is a relationship with other elements.
\end{abstract}

Keywords: play, cognitive development, children aged 1-2 years old

\section{HUBUNGAN PERAN KEGIATAN BERMAIN DALAM PERKEMBANGAN KOGNITIF ANAK USIA 1 - 2 TAHUN}

\begin{abstract}
Abstrak: Orang tua, sekolah dan pemerintah harus memberikan perhatian besar terhadap pendidikan dan pengetahuan anak usia dini. Anak usia dini dibina dan distimulus sesuai dengan keinginan dan kemampuan setiap anak dengan harapan mereka dapat tumbuh sesuai dan berkembang sebagaimana mestinya. Bermain adalah hak setiap anak. Bermain merupakan lahan anak-anak dalam mengekspresikan segala bentuk tingkah laku yang menyenangkan dan tanpa paksaan. Bermain memiliki peran untuk mendukung tumbuh kembang anak terutama dalam perkembangan aspek kognitif. Penelitian ini mengetahui peranan kegiatan bermain terhadap pengetahuan anak usia 1-2 tahun. Penelitian kuantitatif dan Menggunakan paradigma sederhan hubungan dua variabel. Teknik analisis data yang digunakan dalam penelitian ini yaitu analisis Korelasi parametrik perarson product moment. Hasil penelitian Nilai sig $(0.003)<\alpha$ maka H0 ditolak. Sehingga terdapat korelasi antara peranan kegiatan bermain dengan perkembangan kognitif anak 1-2 tahun. Nilai koefesien korelasi menunjukkan pengaruh peranan kegiatan bermain dengan perkembangan kognitif anak 1-2 tahun sebesar 0,598 atau $59,8 \%$. Sehingga korelasi sebesar 40,2\%, kemungkinan ada hubungan unsur lain.
\end{abstract}

Kata Kunci: bermain, perkembangan kognitif, anak usia 1-2 tahun 


\section{PENDAHULUAN}

Potensi yang menjadi penerus citacita bangsa adalah anak usia dini. Mereka adalah para penerus dalam menjalankan perkembangan bangsa dan negara Indonesia. Maka oleh karena itu bagi para orang tua, sekolah dan pemerintah harus memberikan perhatian besar terhadap pendidikan dan pengetahuan anak usia dini. Anak usia dini dibina dan distimulus sesuai dengan keinginan dan kemampuan setiap anak dengan harapan mereka dapat tumbuh sesuai dan berkembang sebagaimana mestinya. Stimulus yang didapat anak usia dini dapat diperoleh dari lingkungannya terutama dari keluarga yaitu orang tua [1]. Bagi anak bermain merupakan persamaan berkerja bagi orang dewasa dan bermain merupakan hal yang terpenting bagi kehidupan anak serta menjadi cara efektif digunakan untuk menurunkan tekanan mental bagi anak baik secara sosial dan emosi [2]. Bermain adalah hak setiap anak. Bermain merupakan lahan anak-anak dalam mengekspresikan segala bentuk tingkah laku yang menyenangkan dan tanpa paksaan. Pada mulanya, bermain dianggap sebagai kegiatan yang dipandang sebelah mata. Awalnya kegiatan bermain belum mendapat perhatian khusus dari para ahli ilmu jiwa, mengingat masih kurangnya pengetahuan tentang psikologi perkembangan anak dan kurangnya perhatian terhadap perkembangan anak pada masa lalu [3]. Namun, dengan kemajuan teknologi dan dukungan hasil penelitian mutakhir menjadikan kegiatan bermain menempati urutan wahid pada kegiatan untuk anak-anak. Kegiatan bermain selalu kita temui dimana ada anakanak, baik disekolah, di rumah, maupun di tempat fasilitas umum. Anak-anak dan bermain bagai dua sisi mata uang yang tak terpisahkan. Anak-anak tak akan lepas dengan kegiatan bermain dan bermain tidak akan terjadi ketika tidak ada anakanak yang ingin bersendau gurau. Bagi orang dewasa kegiatan bermain yang dilakukan anak-anak merupakan hal sepele dan membuang waktu. Namun, tidak untuk anak-anak, dengan bermain mereka dapat mengembangkan aspek sosial, membangun kreativitas, serta mengasah kemampuan fikir dan kebahasaan anak dalam berkomunikasi. Melalui bermain pula anak memahami kaitan antara dirinya dan lingkungan sosialnya [3]. Bermain memiliki peran untuk mendukung tumbuh kembang anak terutama dalam perkembangan aspek kognitif yaitu pengetahuan anak usia dini, namun Sebagian orang tua masih menganggap kegiatan bermain merupakan hal yang membuang waktu percuma serta tidak penting, dan mungkin sering terabaikan dan terlewati masa bermain anak usia dini [4]. Aktivitas bermain pada anak usia dini biasanya dilakukan anak sendiri, Bersama orang tua, keluarga, teman dan para guru. Bermain juga dilakuan secara sukarela tanpa ada paksaan. Bermain juga tidak mengacu pada hasil, namun proses yang dipada hasil. Pada anak usia dini menggunakan kegiatan bermain untuk mempelajari berbagai banyak hal mengenai aturan-aturan, cara bersosialisasi serta mengasah dan mengolah emosi, bagaimana beroleransi serta bekerjasama, dan mempelajari sportivitas merupakan hakikat bermain anak usia dini [5]. Selanjutnya dituturkan oleh Ailwood "Play in early childhood educationforms a significant nodal point at which understanding and discourses of childhood, motherhood, education, family, psychology, and citizenship coagulate and collide, maknanya adalah kegiatan bermain di Lembaga PAUD merupakan pertemuan antara pemahaman dan diskusi yang terjadi pada anak, orang tua dan guru serta psikolong dimana memberikan penguatan pada kenegaraan [6] . Bermain memiliki beberapa esensi bagi anak usia dini yaitu: 1) motivasi internal, anak melakukan kegiatan bermain atas kemauan sendiri ; 2) aktif, anak melakukan kegiatan bermain menggunakan fungsi fisik dan mental; 3) nonliteral, anak melakukan kegiatan bermain apasaja sesuai 
dengan keinginan yang terlepas dari realita seperti bermain pura-pura dan ; 4) bermain dengan berpartisipasi pada kegiatan yang tidak memiliki tujuan secara eksternal yang telah ditetapkan sebelumnya [7]. Bermain memiliki fungsi dan bentuk dengan memiliki manfaat sebagai aktifitas yang menyenagkan bagi anak yang mampu megasah kemampuan aspek perkembangan nilai-nilai agama dan moral, fisik-motorik, kognitif, Bahasa, sosial-emosi serta seni [8].

Kognitif anak merupakan pengetahuan, ingatan, kreativitas, daya fikir, dan daya nalar merupakan hasil bermain dan perkembangan kognitif anak. Anak banyak mengenal mengetahui konsep melalui bermain, karena melalui bermain anak lebih mudah menerima konsep tersebut dari pada melalui ajaran orang dewasa. Maka bermain berguna untuk perkembangan kognitif pada anak usia dini. Ini didukung oleh pendapat beberapa ahli pendidikan anak usia dini salah satunya adalah Maria Montessori. Beliau menyatakan bahwa empat pakta yang dapat menjadi dasar bermain dapat menstimulasi otak anak antara lain ; 1) pikiran yang mencercap; 2) periode kritis; 3) anak adalah makhluk pembelajar; 4) anak belajar dengan bermain [9].

Perkembangan kognitif anak usia 12 tahun tertera pada Lampiran 1 PERMENDIKBUD RI Nomor 137 tahun 2014, tentang standar nasional PAUD standar isi tingkat pencapaian perkembangan anak usia dini. Adapun tertera pada tabel 1 .
Tabel 1. Aspek Perkembangan Kognitif

\begin{tabular}{|c|c|c|}
\hline \multirow{2}{*}{$\begin{array}{l}\text { Lingkup } \\
\text { Perkembangan }\end{array}$} & \multicolumn{2}{|c|}{$\begin{array}{l}\text { Tingkat Pencapaian Perkembangan } \\
\text { Anak }\end{array}$} \\
\hline & $12-18$ bulan & $18-24$ bulan \\
\hline \multicolumn{3}{|l|}{ III. Kognitif } \\
\hline \multirow[t]{4}{*}{$\begin{array}{l}\text { A.Belajar dan } \\
\text { Pemecahan } \\
\text { Masalah }\end{array}$} & $\begin{array}{l}\text { 1. Menyebut } \\
\text { beberapa nama } \\
\text { benda, jenis } \\
\text { makanan }\end{array}$ & $\begin{array}{l}\text { 1. Mempergunakan } \\
\text { alat permainan } \\
\text { dengan cara } \\
\text { memainkannya } \\
\text { tidak beraturan, } \\
\text { seperti balok } \\
\text { dipukul-pukul }\end{array}$ \\
\hline & $\begin{array}{l}2 . \\
\text { Menanyakan } \\
\text { nama benda } \\
\text { yang belum } \\
\text { dikenal }\end{array}$ & $\begin{array}{l}\text { 2. Memahami } \\
\text { gambar wajah } \\
\text { orang }\end{array}$ \\
\hline & $\begin{array}{l}\text { 3. Mengenal } \\
\text { beberapa } \\
\text { warna dasar } \\
\text { (merah, biru, } \\
\text { kuning, hijau) }\end{array}$ & $\begin{array}{l}\text { 3. Memahami milik } \\
\text { diri sendiri dan } \\
\text { orang lain seperti: } \\
\text { milik saya, milik } \\
\text { kamu }\end{array}$ \\
\hline & $\begin{array}{l}\text { 4. Menyebut } \\
\text { nama sendiri } \\
\text { dan orang- } \\
\text { orang yang } \\
\text { dikenal }\end{array}$ & $\begin{array}{l}\text { 4. Menyebutkan } \\
\text { berbagai nama } \\
\text { makanan dan } \\
\text { rasanya } \\
\text { (misal,garam-asin, } \\
\text { gula-manis) }\end{array}$ \\
\hline \multirow[t]{3}{*}{$\begin{array}{l}\text { B.Berpikir } \\
\text { Logis }\end{array}$} & $\begin{array}{l}\text { 1. } \\
\text { Membedakan } \\
\text { ukuran benda } \\
\text { (besar- kecil) }\end{array}$ & $\begin{array}{l}\text { 1.Menyusun balok } \\
\text { dari besar ke kecil } \\
\text { atau sebaliknya }\end{array}$ \\
\hline & $\begin{array}{l}2 . \\
\text { Membedakan } \\
\text { penampilan } \\
\text { yang rapi atau } \\
\text { tidak }\end{array}$ & $\begin{array}{l}\text { 2.Mengetahui } \\
\text { akibat dari suatu } \\
\text { perlakuannya } \\
\text { (misal: menarik } \\
\text { taplak meja akan } \\
\text { menjatuhkan } \\
\text { barang-barang di } \\
\text { atasnya) }\end{array}$ \\
\hline & $\begin{array}{l}\text { 3. Merangkai } \\
\text { puzzle } \\
\text { sederhana }\end{array}$ & 3.Merangkai puzzle \\
\hline $\begin{array}{l}\text { C. Berpikir } \\
\text { Simbolik }\end{array}$ & $\begin{array}{l}1 . \\
\text { Menyebutkan } \\
\text { bilangan tanpa } \\
\text { menggunakan } \\
\text { jari dari } 1-10 \\
\text { tetapi masih } \\
\text { suka ada yang } \\
\text { terlewat }\end{array}$ & $\begin{array}{l}\text { 1. Menyebutkan } \\
\text { angka satu sampai } \\
\text { lima dengan } \\
\text { menggunakan jari }\end{array}$ \\
\hline
\end{tabular}

Sumber [10].

Aspek kognitif anak akan berkembang dengan baik dan optimal jika diberikan kegiatan-kegiatan stimulus yang tepat. Penunjang perkembangan yang dimiliki anak melibatkan peranan bermain terutama dalam 
lingkungan keluarga, proses interkasi kegiatan-kegiatan bermain ini yang dapat memicu perkembangan kognitif anak, sehingga dalam penyerapan pengetahuan anak itu lebih mudah. Cara berfikir anak yaitu oprasional konkrit, menyerap pengetahuan dengan hal-hal dan bendabenda yang nyata [11]. Namun ada beberapa alasan yang terdiri beberapa faktor lain yang mempengaruhi perkembangan kognitif anak yaitu genetik (bawaan) dan lingkungan anak. Setiap orang tua mengharapkan anak mereka memiliki pengetahuan dan kecerdasan, ini diperoleh tidak saja melalui stimulus tapi juga melalui asupan makanan yang bergizi [4]. Maka Tujuan dalam penelitian ini adalah untuk mengetahui hubungan peran kegiatan bermain dalam perkembangan kognitif anak usia 1 - 2 tahun.

\section{METODE PENELITIAN}

Penelitian ini menggunakan jenis penelitian kuantitatif. Menggunakan paradigma sederhan hubungan dua variabel. Subjek penelitian menggunakan Teknik purposive sampling yaitu penentuan sampel dengan pertimbangan tertentu dan sampel ditentukan atas dasar rekomendasi [12]. Penelitian ini menggunakan alat pengumpulan data dengan menggunakan angket. Teknik analisis data yang digunakan dalam penelitian ini yaitu analisis Korelasi parametrik perarson product moment dimana mengetahui hubungan dua veriabel. Jenis yang digunakan adalah korelasi bivariat [13].

\section{HASIL DAN PEMBAHASAN}

Berikut ini merupakan hasil penjabaran penelitian hubungan peran kegiatan bermain dalam perkembangan kognitif anak usia 1 - 2 tahun.
1. Kegiatan bermain

Tabel 2. hasil penghitungan rata-rata kegiatan bermain

\begin{tabular}{|c|c|c|c|c|c|}
\hline & & Freq. & Percent & $\begin{array}{c}\text { Valid } \\
\text { Percent }\end{array}$ & $\begin{array}{l}\text { Cumu- } \\
\text { lative } \\
\text { Percent }\end{array}$ \\
\hline \multirow{3}{*}{ Valid } & $\begin{array}{l}\text { Tidak } \\
\text { Pernah }\end{array}$ & 7 & 30.4 & 30.4 & 30.4 \\
\hline & Pernah & 16 & 69.6 & 69.6 & \multirow[t]{2}{*}{100.0} \\
\hline & Total & 23 & 100.0 & 100.0 & \\
\hline
\end{tabular}

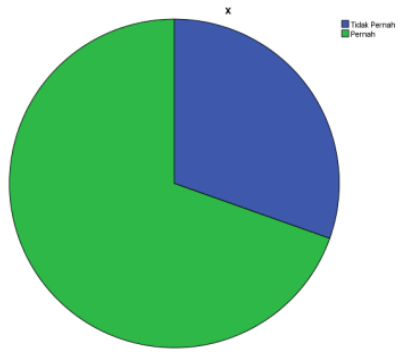

Gambar.1. Persentase kegiatan bermain anak

Dari hasil analisis frefekuensi untuk variabel peranan kegiatan bermain jumlah proporsi dalam proses persen. Table di atas mengjabarkan bawa kegiatan bermain sebanyak 30,4\% tidak pernah dan 69,6\% pernah melakukan kegiatan bermain tersebut. Dari hasil tersebuat dapat dikatakan bahwa tingkat persentase yang tidak pernah cukup tinggi maka dapat diketahui masih banyak orang tua yang kurang memberikan kegiatan stimulus bagi anaknya terutama saat di usia 12 tahun.

2. Kemampuan pengetahuan anak usia 1-2 tahun

Tabel 3. hasil penghitungan rata-rata kemampuan kognitif anak 1-2 tahun

\begin{tabular}{rl|r|r|r|r}
\hline & Freq. & Percent & $\begin{array}{c}\text { Valid } \\
\text { Percent }\end{array}$ & $\begin{array}{c}\text { Cumu- } \\
\text { lative } \\
\text { Percent }\end{array}$ \\
\hline \multirow{4}{*}{ Valid } & Belum Bisa & 4 & 17.4 & 17.4 & 17.4 \\
Cukup & 9 & 39.1 & 39.1 & 56.5 \\
Bisa & 10 & 43.5 & 43.5 & 100.0 \\
& Sangat & & & \\
Bisa & 23 & 100.0 & 100.0 & \\
Total & &
\end{tabular}




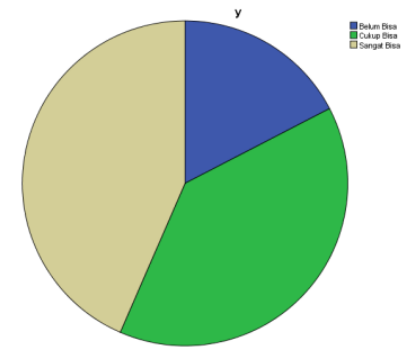

Gambar.2. Persentase perkembangan kognitif anak

Dari hasil analisis frefekuensi untuk variabel perkembangan kognitif anak usia 1-2 tahun jumlah proporsi dalam proses persen. Table di atas mengjabarkan bawa perkembnagan kognitif anak sebanyak $17,4 \%$ belum bisa, $39,1 \%$ cukup bisa dan $43,5 \%$ sangat bisa. Berarti dari hasi tersebuat menginfokan bahwa kemamuan anak yang sudah sangat bisa tidak mencapai 50\%, maka dapat disimpulkan bawa anak usia 1-2 tahun masih perlu banyak diberikan perhatian dengan memberikan stimulus yang banyak dengan berbagai cara untuk mengasah perkembangan anak terutama pada kemampuan perkembangan kognitif.

3. Hubungan peranan kegiatan bermain dalam perkembangan kognitif anak usia 1-2 tahun

Table 4. Hasil Tes of Normality Tests of Normality

\begin{tabular}{|c|c|c|c|c|c|c|}
\hline & \multicolumn{3}{|c|}{$\begin{array}{c}\text { Kolmogorov- } \\
\text { Smirnov }^{\mathrm{a}}\end{array}$} & \multicolumn{3}{|c|}{ Shapiro-Wilk } \\
\hline & Statistic & $\mathrm{df}$ & Sig. & Statistic & $\mathrm{df}$ & Sig. \\
\hline Y & .152 & 23 & .183 & .920 & 23 & .067 \\
\hline $\mathrm{X}$ & .125 & 23 & $.200^{*}$ & .956 & 23 & .393 \\
\hline
\end{tabular}

Berdasarkan hasil table tes normalitas di maka data yang didapat adalah nilai hasil metode kolmogorovsmirnov mendapatkan hasil 0.183 untuk nilai perkembangan kognitif anak 1-2 tahun dan 0,200 untuk peranan kegiatan bermain, sedangkan shapiro-wilk hasil 0,067 perkembangan kognitif anak 1-2 tahun dan 0,393 peranan kegiatan bermain. Dikarenakan nilai sig $>\alpha(0,005)$ maka distribusinya Normal, namun sebaliknya jika sig $<\alpha(0,005)$ maka distribusinya tidak normal [14]. Maka berdasarkan hasil di atas data penelitian ini normal.

Table 5. Hasil Correlation Correlations

\begin{tabular}{rl|r|r}
\hline & VAR00007 & VAR00008 \\
\hline \multicolumn{2}{c|}{ Pearson } & 1 & $.598^{* * *}$ \\
Y Correlation & & .003 \\
& Sig. (2-tailed) & & 23 \\
& N & $.598^{* *}$ & 1 \\
& Pearson Correlation & .003 & \\
X $\quad$ Sig. (2-tailed) & 23 & 23 \\
\hline
\end{tabular}

**. Correlation is significant at the 0.01 level (2-tailed).

Berdasarkan hasil tabel 5 diatas Nilai sig $(0.003)<\alpha$ maka H0 ditolak. Sehingga terdapat korelasi antara peranan kegiatan bermain dengan perkembangan kognitif anak 1-2 tahun. Nilai koefesien korelasi menunjukkan pengaruh peranan kegiatan bermain dengan perkembangan kognitif anak 1-2 tahun sebesar 0,598 atau $59,8 \%$. Sehingga korelasi sebesar 40,2\%, kemungkinan ada hubungan unsur lain. Periode infacy period adalah rentang perkembangan anak usia 0-2 tahun, masa dimana anak masih tergantung dengan orang dewasa dimana perkembangan anak di stimulus melalui berbagai kegiatan bermain yang menjadi permualaan anak mengenal hal yang mengasah kemampuan kognitif [15].

Dari hasil penghitungan diatas maka sesuai dengan teori yang diungkapkan oleh Maria Montessori yang menjabarkan bahwa bermain terdiri dari empat fakta mendasar dalam menstimulasi otak anak, yaitu pertama adalah pikiran yang mencercap, kedua adalah periode kritis, ketiga anak meripakan mahluk pembelajar yang banyak rasa ingin tahu dan yang keempat anak belajar dan mendapat 
pengetahuan melalui bermain [16]. Melalui bermain maka dapat mendukung tumbuh kembang anak tidak hanya dari aspek perkembangan kognitif saja tapi juga aspek lainnya [4].

\section{KESIMPULAN}

Bermain memiliki peran untuk mendukung tumbuh kembang anak terutama dalam perkembangan aspek kognitif yaitu pengetahuan anak usia dini, namun Sebagian orang tua masih menganggap kegiatan bermain merupakan hal yang membuang waktu percuma serta tidak penting, dan mungkin sering terabaikan dan terlewati masa bermain anak usia dini [4].

Bermain memiliki fungsi dan bentuk dengan memiliki manfaat sebagai aktifitas yang menyenagkan bagi anak yang mampu megasah kemampuan aspek perkembangan nilai-nilai agama dan moral, fisik-motorik, kognitif, Bahasa, sosial-emosi serta seni [8]. Kognitif anak merupakan pengetahuan, ingatan, kreativitas, daya fikir, dan daya nalar merupakan hasil bermain dan perkembangan kognitif anak.

Berarti dari hasi tersebuat menginfokan bahwa kemamuan anak yang sudah sangat bisa tidak mencapai 50\%, maka dapat disimpulkan bawa anak usia 12 tahun masih perlu banyak diberikan perhatian dengan memberikan stimulus yang banyak dengan berbagai cara untuk mengasah perkembangan anak terutama pada kemampuan perkembangan kognitif.

Hubungan peranan kegiatan bermain dalam perkembangan kognitif anak usia 12 tahun. Hasil tests of Normality Tests of Normality Kolmogorov-Smirnova ShapiroWilk Statistic df Sig. Berdasarkan hasil tes normalitas di maka data yang didapat adalah nilai hasil metode kolmogorovsmirnov mendapatkan hasil 0.183 untuk nilai perkembangan kognitif anak 1-2 tahun dan 0,200 untuk peranan kegiatan bermain, sedangkan shapiro-wilk hasil 0,067 perkembangan kognitif anak 1-2 tahun dan 0,393 peranan kegiatan bermain. Periode infacy period adalah rentang perkembangan anak usia 0-2 tahun, masa dimana anak masih tergantung dengan orang dewasa dimana perkembangan anak di stimulus melalui berbagai kegiatan bermain yang menjadi permualaan anak mengenal hal yang mengasah kemampuan kognitif [15].

Dari hasil penghitungan diatas maka sesuai dengan teori yang diungkapkan oleh Maria Montessori yang menjabarkan bahwa bermain terdiri dari empat fakta mendasar dalam menstimulasi otak anak, yaitu pertama adalah pikiran yang mencercap, kedua adalah periode kritis, ketiga anak meripakan mahluk pembelajar yang banyak rasa ingin tahu dan yang keempat anak belajar dan mendapat pengetahuan melalui bermain [16].

\section{DAFTAR PUSTAKA}

[1] S. Haryani, "Hubungan antara Pengetahuan dan Motivasi Dengan kKnerja Perawat Dalam Pelaksanaan Terapi Bermain Pada Anak Usia Prasekolah Di Ruang Rawat Inap Anak RSUP Dr. Kariadi Semarang," in PROSIDING KONFERENSI NASIONAL II PPNI, 2014, pp. 249252.

[2] Nursalam, Asuhan Keperawatan Bayi dan Anak (untuk Perawat dan Bidan). Jakarta: Salemba Medika., 2005.

[3] M. T. Sugianto, Bermain, Mainan, dan Permainan. Jakarta: DEPDIKBUD, 1995.

[4] D. Murtiningsih, "Peran Orangtua Dalam Kegiatan Bermain Anak Usia Dini (4-6 Tahun) Di Rumah," J. Pendidik. Luar Sekol., vol. 9, no. 2, pp. 1-21, 2013.

[5] Mulyasa, Manajemen PAUD. Bandung: PT Remaja Rosdakarya, 2014.

[6] J. Ailwood, "Governing Early Childhood Education through Play," Contemp. Issues Early Child., vol. 4, 
no. 3, pp. 286-299, 2003, doi: 10.2304/ciec.2003.4.3.5.

[7] S. Suyanto, Konsep Dasar PAUD. Jakarta: DEPDIKBUD, 2005.

[8] J. W. Santrock, Life Span. New York: Mac Graw Hill, 2012.

[9] Suyadi, Teori pembelajaran Anak Usia Dini: dalam kajian Neurosains. Bandung: PT Remaja Rosdakarya, 2014.

[10] Kemdikbud, "Peraturan Menteri Pendidikan dan Kebudayaan Republik Indonesia Nomor 137 Tahun 2014 Lampiran 1 Standar Isi PAUD," vol. 31, pp. 1-31, 2017.

[11] I. S. \& H. Kurniasari, "Penggunaan Media Alam Sekitar dan Kemampuan Berfikir Logis Anak Usia Dini," J. FKIP UNILA, no. 1, 2018.

[12] R. Mukhsin, P. Mappigau, and A. N. Tenriawaru, "Pengaruh Orientasi Kewirausahaan Terhadap Daya Tahan Hidup Usaha Di Kota Makassar," J. Anal., vol. 6, no. 2, pp. 188-193, 2017.

[13] N. P. Marlina, N. N. M. A. Minarti, and N. K. C. Utami, "HUBUNGAN BERMAIN GAME ONLINE DENGAN PRESTASI BELAJAR MATEMATIKA ANAK USIA SEKOLAH KELAS V DI SEKOLAH DASAR SARASWATI I DENPASAR TAHUN 2014," no. 2011, 2014.

[14] C. Trihendradi, IBM SPSS 21. Yogyakarta: Andi, 2013.

[15] Khadijah, Pengembangan Kognitif Anak Usia Dini. Medan: Kelompok Penerbit Perdana Mulya Sarana, 2016.

[16] Naili Rohmah, "Bermain Dan Pemanfaatannya Dalam Perkembangan Anak Usia Dini," J.
Tarbawi, vol. 13, no. 2, pp. 27-35, 2016. 